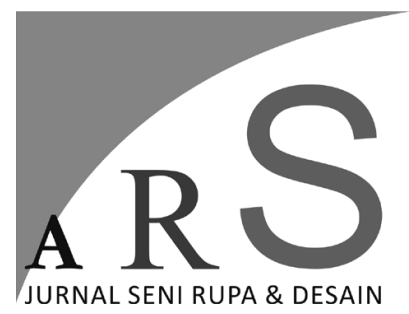

Volume 23 Nomor 3 September - Desember 2020

\section{ANALISIS MAKNA DAN BENTUK BUSANA ADAT DAHA DAN TRUNA DESA BUNGAYA KARANGASEM}

\author{
Ni Putu Elsye Andriani Delfina, I Wayan Mudra, I Wayan \\ Swandi
}

Institut Seni Indonesia Denpasar, Bali - Indonesia

Jl. Nusa Indah Denpasar, Telp. 082144253430 ,

E-mail: elsye.andriani@yahoo.com,wayanmudra@isi-dps.ac.id, wayanswandi@gmail.com

\begin{abstract}
ABSTRAK
Busana adat daha dan truna Desa Bungaya adalah busana yang wajib digunakan saat upacara Dewa Yadnya yang biasanya berlokasi di Pura Bale Agung Desa Bungaya Karangasem. Busana adat daha dan truna ini merupakan salah satu bagian unik dari adat dan tradisi yang sudah diwariskan turun-temurun oleh leluhur di Desa Bungaya. Busana adat ini secara visual nampak sangat sederhana namun memiliki filosofi yang erat kaitannya dengan nilai-nilai dalam agama. Oleh karena itu bentuk yang menyusun busana ini memiliki makna yaitu makna konotatif dan denotatif. Makna dalam satu bentuk atau bentuk lainnya, menyampaikan pengalaman sebagian besar umat manusia di semua masyarakat dan bentuk menjadi begitu penting karena mampu mempengaruhi perasaan estetis para penikmat seni ketika pertama melihat suatu karya seni rupa. Adapun tujuan dalam penulisan ini adalah untuk mengetahui lebih dalam tentang bagaimana unsur pada desain mode yang terkandung didalamnya yaitu bentuk dalam busana adat daha dan truna di Desa Bungaya yang mengandung suatu makna. Penulisan ini menggunakan metode penelitian deskriptif kualitatif dengan teknik pengumpulan data observasi, wawancara dan kepustakaan. Berdasarkan analisa data yang dilakukan, didapat kesimpulan yaitu unsur bentuk dalam busana adat daha dan truna terdapat bentuk geometris, non geometris dan bentuk siluet yang menyusun busana adat dan dalam bentuk tersebut mengandung makna konotatif dan denotatif.
\end{abstract}

Kata kunci: busana adat, daha dan truna, desa bungaya, makna konotatif dan denotative

\begin{abstract}
Analysis Of Meaning And Form Daha Traditional Clothes And Truna Village Bungaya Karangasem. The daha and truna traditional clothes of Bungaya Village are clothes that must be used during the Yadnya Dewa ceremony which is usually located in Pura Bale Agung, Bungaya Karangasem Village. Daha and truna traditional clothing is one of the unique parts of customs and traditions that have been passed down from generation to generation by the ancestors in Bungaya Village. This traditional dress visually seems very simple but has a philosophy that is closely related to values in religion. Therefore the form that compiles this outfit has a meaning that is connotative and denotative. Meaning in one form or another, conveying the experience of most human beings in all societies and forms becomes so important because it is able to influence the aesthetic feelings of art lovers when first seeing a work of art. The purpose of this paper is to find out more about how the elements of the fashion design contained therein are the forms in the traditional dress of the daha and truna in Bungaya Village which contain a meaning. This writing uses descriptive qualitative research methods with data collection techniques of observation, interviews and literature. Based on the data analysis, the conclusion is that the form elements in the traditional dress of the daha and truna are geometric, non-geometric and silhouette shapes that make up the traditional clothing and in that form contain connotative and denotative meanings.
\end{abstract}

Keywords : traditional clothing, daha and truna, bungaya village, connotative and denotative meaning 


\section{Pendahuluan}

Busana tradisional merupakan busana yang dapat mencerminkan suatu norma atau nilainilai budaya suatu etnis yang memilikinya. Dalam kebudayaan masyarakat Bali busana merupakan unsur kebudayaan yang sangat penting. Busana adat dapat juga memiliki nilai filosofis yang berkaitan dengan agama dan tradisi. Berdasarkan pada nilai-nilai tersebut sebagai pendukung pertumbuhan dan perkembangan busana adat sebagai ragam dari busana daerah sebagai karya budaya yang mengaggumkan. Melalui busana adat tradisional tersebut dapat melihat kekayaan warisan budaya yang tidak saja terlihat teknik pembuatan busana, aneka ragam corak pada busana serta jenis kain yang digunakan. Akan tetapi, dapat juga dikenal berbagai fungsi dan arti kain dalam kehidupan masyarakat Indonesia yang mencerminkann adat istiadat, kebudayaan, dan kebiasaan budaya (culturalhabit), yang bermuara pada jati diri masyarakat Indonesia (Budiwanti, 2000:11).

Busana adat yang dipergunakan untuk upacara-upacara kerajaan dapat dilihat sebagai satu simbol identitas, yang terkait dengan hak dan kewajiban pemakainya (Condronegoro, 1995: 3). Salah satu contohnya yaitu busana adat daha dan truna di Desa Bungaya Karangasem. Masyarakat di Desa Bungaya masih percaya dengan pemaknaan suatu tradisi. Kepercayaan masyarakat setempat dengan berbagai upacara adat atau biasa disebut dengan usaba yang merepresentasikan rasa syukur masyarakat desa atas kesuburan dan kehidupan di Desa Bungaya, Dapat dilihat dari struktur kemasyarakatan yang masih sangat tradisional, tidak hanya itu cara berbusana di desa ini juga diatur oleh awig-awig. Busana yang digunakan sesuai dengan jabatan adat seseorang di desa setempat. Salah satunya yaitu daha dan truna di Desa Bungaya.

Daha dan truna di desa ini memiliki busana khusus yang digunakan dalam acara-acara Dewa Yadnya di Pura Bale Agung yang biasanya berkaitan dengan upacara usaba. Pemaknaan tersebut dapat terlihat dalam kehidupan seharihari masyarakat yang bersangkutan melalui hubungan secara vertikal, horizontal, dan selalu dikaitkan dengann pelaksanaan konsep sosio religi dimana dalam hal ini yaitu perayaan upacara Dewa Yadnya atau biasa yang disebut dengan ngusaba.

Busana adat daha dan truna di Desa Bungaya memiliki keunikan dari segi bentuk dimana dalam hal ini berkaitan dengan makna pada busana tersebut. Busana adat daha dan truna memiliki kesan sederhana namun memiliki nilai keagungan. Keunikan pada bentuk itulah yang menghasilkan suatu pemaknaan berupa abtsrak hingga naturalis. Bentuk pada busana ini juga memiliki kaitan dengan nilai filosofi Hindu yang kuat sehingga menjadi daya tarik penulis untuk mengkaji secara lebih dalam. Bentuk ini adalah suatu ciri objektif suatu karya seni, dalam seni rupa, bentuk adalah penggabungan berbagai garis, warna, ruang, bidang, tekstur dan gelapterang. Bentuk mampu mempengaruhi perasaan estetis para penikmat seni ketika pertama melihat suatu karya seni rupa. Perasaan estetis adalah perasaan seseorang yang tergugah oleh bentuk yang dapat menarik perhatian (dalam Gie, 1996:31). Oleh karena itu bentuk menjadi hal yang penting, dari bentuk akan menghasilkan tanggapan yang berasal dari imajinasi penikmat seni maka lahirlah yang disebut sebagai isi atau arti dari sebuah karya seni atau disebut juga makna.

\section{Pembahasan}

\section{Hasil}

Busana adat daha dan truna Desa Bungaya Karangasem merupakan busana yang memiliki nilai keindahan jika dilihat secara visual dengan panca indera. Perpaduan warna, garis, tekstur pada busana ini menjadi bentuk dinamis dengan kesan sakral. Busana adat daha dan truna terbagi dari 3 bagian, atau disebut juga dengan konsep Tri Angga. Pada konsep ini merupakan pakem atau aturan dalam menggunakan busana adat di Bali. Pada busana adat daha dan truna busana terbagi menjadi 3 yaitu, kepala, badan dan kaki. 


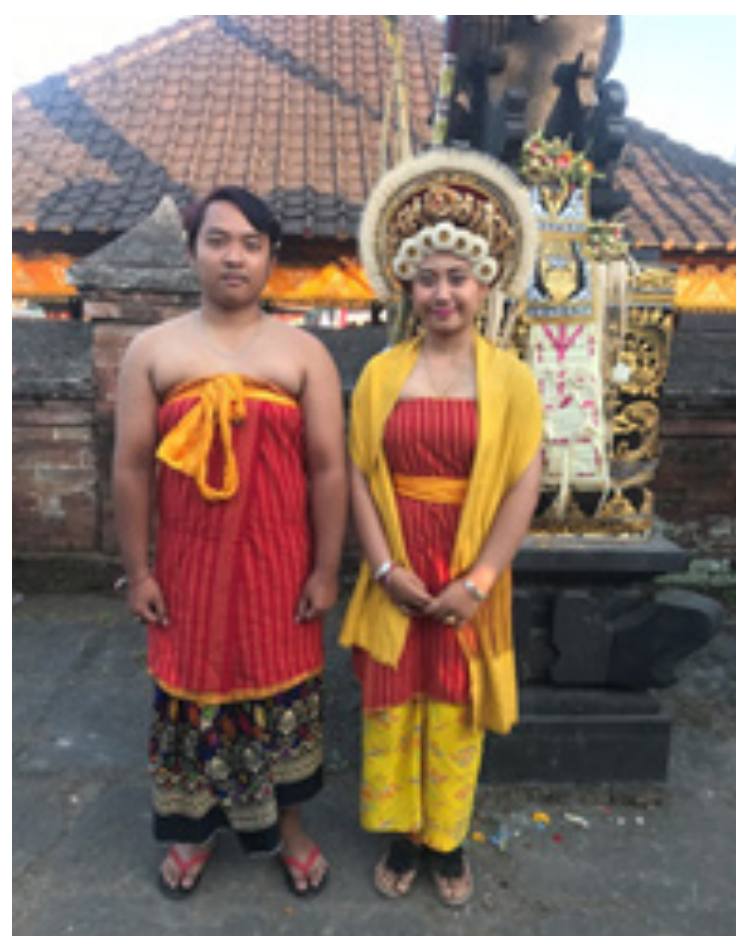

Gambar 1 Busana adat daha dan truna (Sumber: Elsye Andriani, 2019)

Untuk busana daha bagian kepala terdiri dari gelungan plendo, bunga onggar, bunga semanggi, pusung gaton yang dihias bunga serombyong (dibuat dari kertas putih), bunga sandat. Hiasan pada badan gelang perak pada dua pergelangan tangan, saput karah, senteng dan selendang yang dikenakan di bahu disebut sampet. Pada bagian bawah menggunakan kain tenunan Bali (bebas). Busana truna lebih sederhana jika dibandingkan dengan daha.

Pada truna bagian kepala tidak menggunakan destar, pada bagian badan menggunakan kain untuk melelancingan, saput karah, umpal dan keris. Seluruh atribut yang digunakan merupakan benda-benda yang disakralkan. Khusus untuk selendang dan saput karah yang digunakan oleh daha dan truna tidak boleh dicuci dengan air biasa, melainkan harus menggunakan air yang diambil dari beji saga (sumber mata air). Hal ini menunjukan selain keindahan pada wujud atau bentuknya namun busana ini memiliki makna-makna terkait tentang ritual keagamaan di Desa Bungaya Karangasem. Jika dilihat secara estetika, unsur-unsur seni yang sangat melekat pada busana ini adalah bentuk.
Pada busana ini terdapat berbagai bentuk yang menyusun busana tersebut, diantaranya yaitu bentuk non geomteris seperti bentuk bungabunga pada hiasan kepala, dan bentuk keris. Untuk bentuk geomteris terdiri dari persegi dan lingkaran. Selain itu terdapat juga bentuk siluet pada busana ini yaitu siluet I dan $\mathrm{H}$.

\section{1). Bentuk Geometris Pada Busana Adat Daba dan Truna Desa Bungaya Karangasem}

Bentuk geometris pada busana yang digunakan daha terdiri dari: plendo (hiasan di bagian kepala yang berwarna putih) berbentuk geometris yaitu lingkaran,. Pada bagian pergelangan tangan terdapat gelang perak dengan ukiran ornamen dengan bentuk geometris lingkaran. Pada bagian badan terdapat kain yang disebut saput karah yang digunakan menutup dada hingga lutut yang berbentuk geometris persegi. Pada bagian atas yang menutupi lengan terdapat kain selendang/samped berwarna kuning yang berbentuk persegi panjang. Selain itu terdapat juga selendang berwarna kuning yang diikat pada bagian pinggang. Selanjutnya pada bagian dalam menggunakan kamen yang berbentuk geometris persegi yang setengah bagiannya ditutupi oleh saput karah.

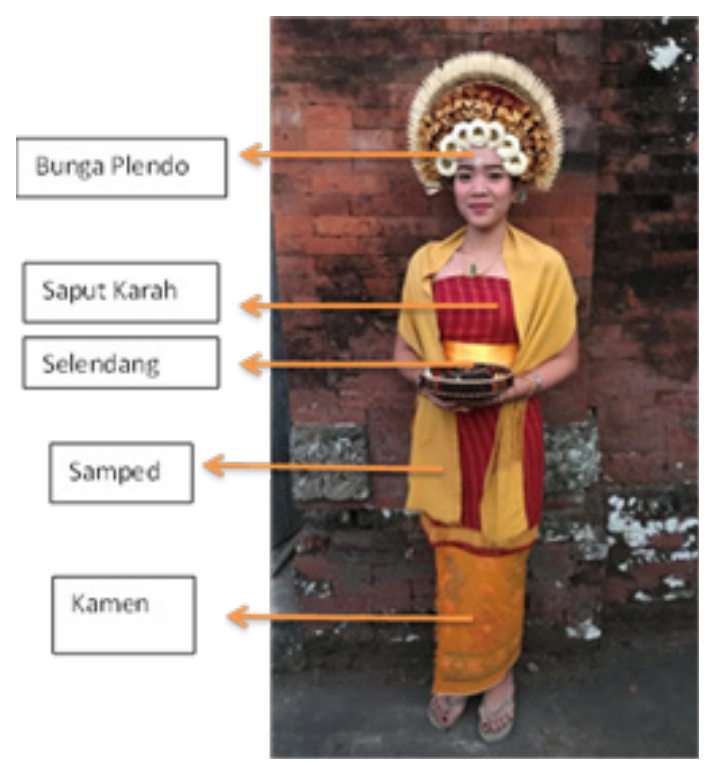

Gambar 2 Busana adat daha (Sumber: Elsye Andriani, 2019) 
Untuk busana truna lebih sederhana dibandingkan daha. Busana truna terdiri dari saput karah yang berbentuk persegi, selanjutnya menggunakan selendang pada bagian dada yang berbentuk persegi panjang dan menggunakan kamen dengan bentuk persegi.

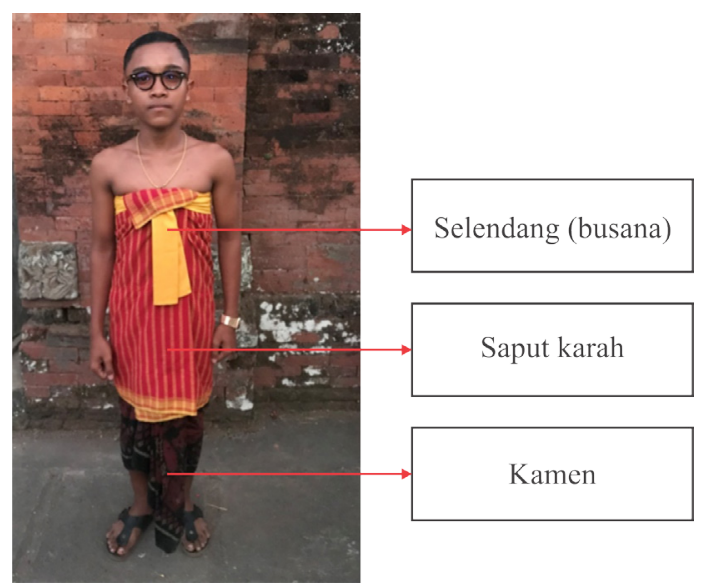

Gambar 3 Busana adat truna (Sumber: Elsye Andriani, 2019)

2). Bentuk Non Geometris Pada Busana Adat Daha dan Truna Desa Bungaya Karangasem

Pada busana adat daha dan truna Desa Bungaya juga terdapat beberapa bentuk non geometris. Pada daha bagian kepala terdapat gelungan yang dihias dengan bunga emas berbentuk flora, bagian atas gelungan juga dihias dengan kayu yang berbentuk lancip. Pada bagian kepala belakang menggunakan hiasan yang menjuntai memanjang kesamping berwarna putih yang berbentuk lancip.

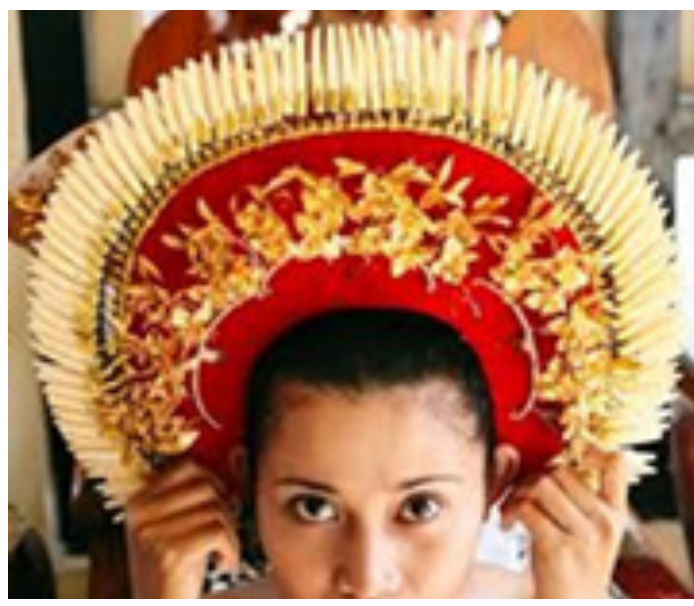

Gambar 4 Gelungan daha (Sumber: www.google.com)

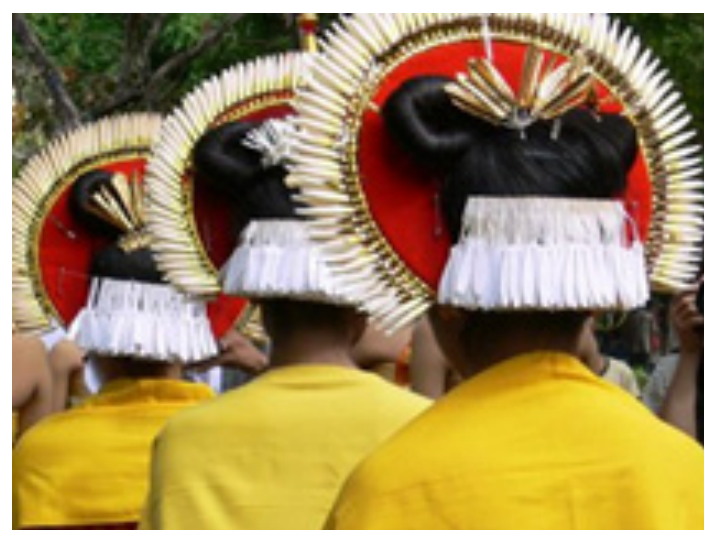

Gambar 5 Gelungan daha

(Sumber: www.google.com)

Sedangkan bentuk non geometris pada truna terdapat keris yang ditempatkan pada bagian belakang yaitu punggung.

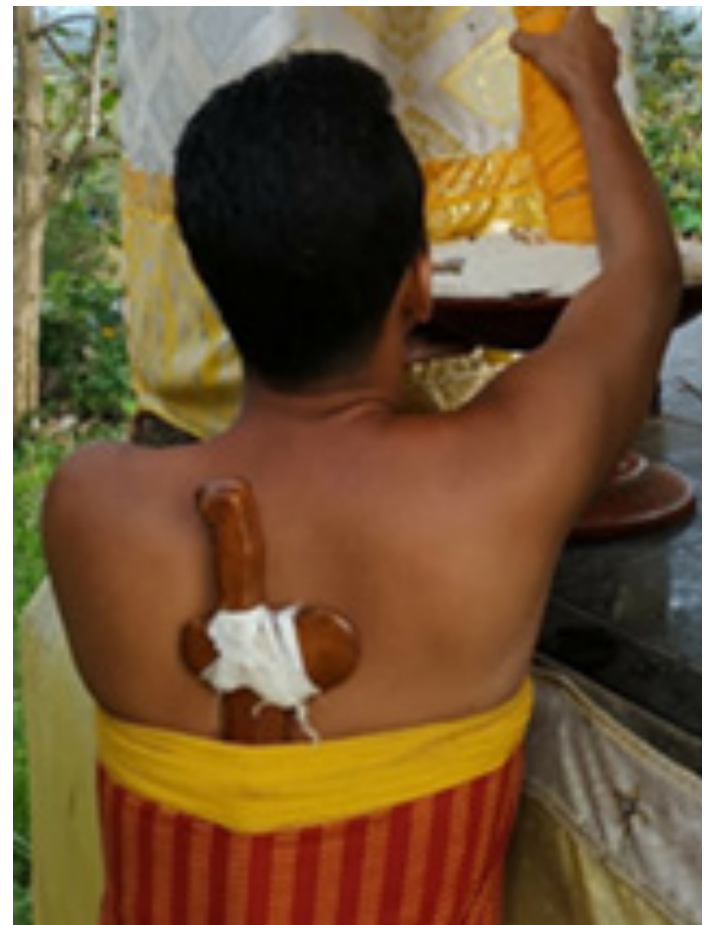

Gambar 6 Keris truna (Sumber: www.google.com)

3). Bentuk Siluet Busana Adat Daha dan Teruna Desa Bungaya Karangasem

Secara keseluruhan bentuk siluet pada busana adat daha dan truna Desa Bungaya menggunakan siluet $\mathrm{H}$ dan I. Siluet $\mathrm{H}$ merupakan siluet yang mengambil bentuk lurus tanpa mengikuti bentuk tubuh si pemakainya. Siluet $H$, merupakan bentuk 
pakaian yang longgar, simple, praktis, dan fleksibel. Biasanya siluet $\mathrm{H}$ terlihat pada busana formal maupun busana santai. Dan siluet I merupakan siluet yang dari atas hingga bawah bentuknya lurus sehingga menyerupai huruf I. Siluet I pada busana merupakan siluet palimg sederhana karena tidak terdapat lekukan pada pagian sisinya. Pada busana adat daha dan truna Desa Bungaya penggunaan busana dan bentuk siluet sangat sederhana. Namun dibalik kesederhanaan itu tersimpan makna yang mendalam. Tampilan sederhana dari busana tersebut tidak menghilangkan nilai estetika dari busana adat tersebut. Busana adat yang sederhana ini memiliki taksu yang tidak dimiliki oleh yang lain.

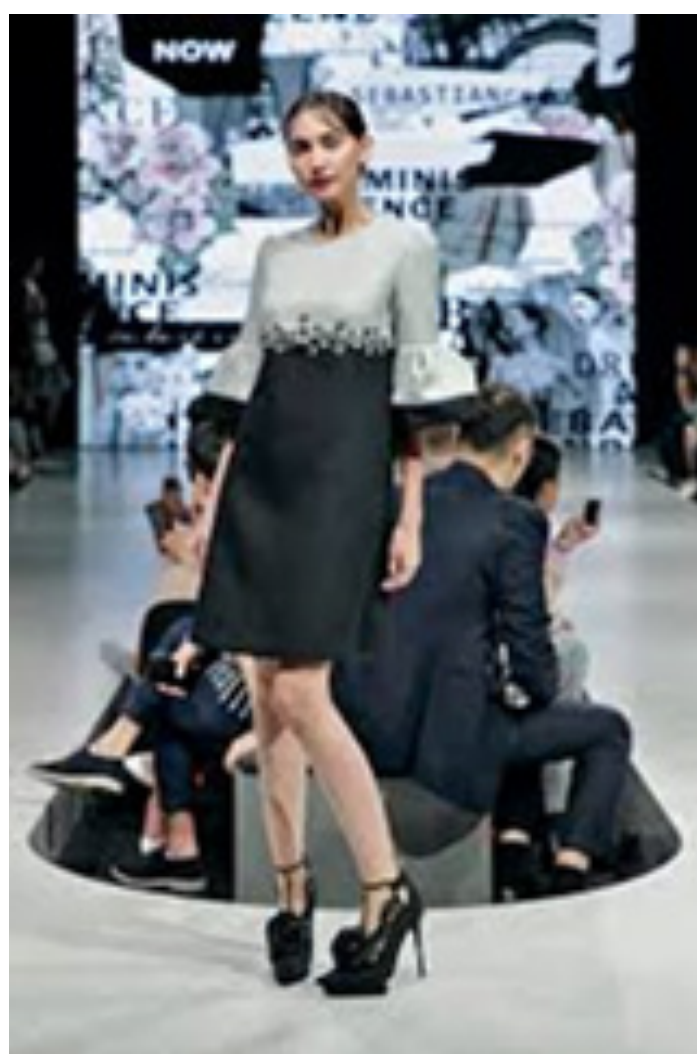

Gambar 7 Busana dengan siluet $\mathrm{H}$ (Sumber: www.google.com)

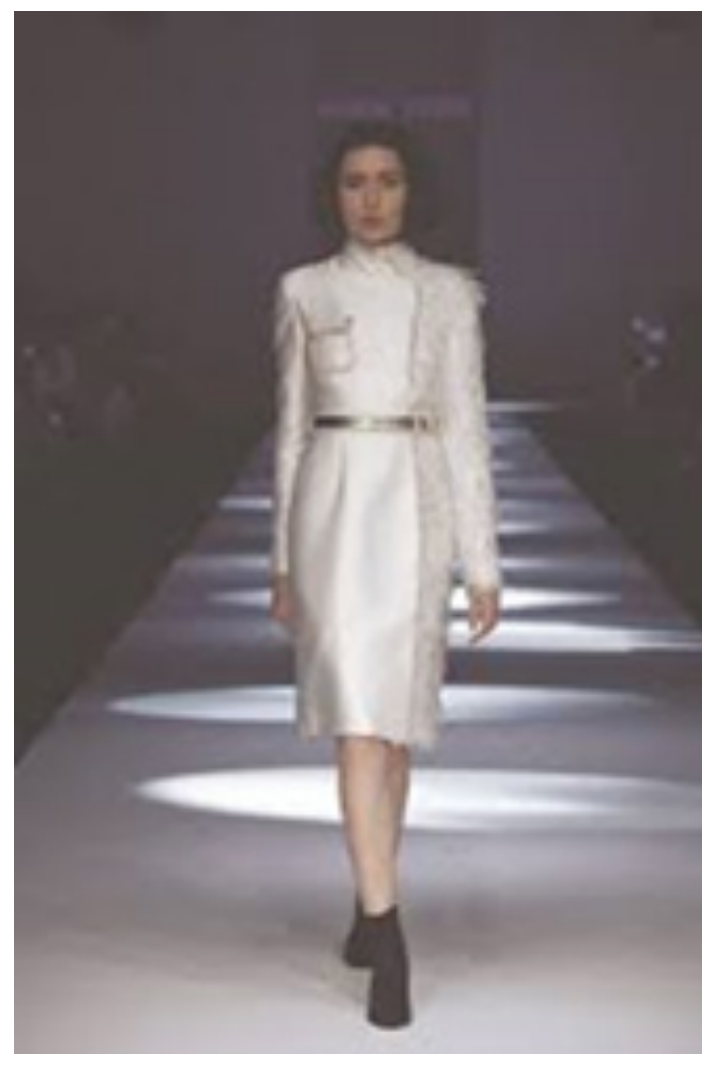

Gambar 8 Busana dengan siluet I (Sumber: www.google.com)

Secara keseluruhan bentuk siluet pada busana adat daha dan truna Desa Bungaya menggunakan siluet $\mathrm{H}$ dan I . Siluet $\mathrm{H}$ merupakan siluet yang mengambil bentuk lurus tanpa mengikuti bentuk tubuh si pemakainya. Siluet $\mathrm{H}$, merupakan bentuk pakaian yang longgar, simple, praktis, dan fleksibel. Biasanya siluet $\mathrm{H}$ terlihat pada busana formal maupun busana santai. Dan siluet I merupakan siluet yang dari atas hingga bawah bentuknya lurus sehingga menyerupai huruf I. Siluet I pada busana merupakan siluet palimg sederhana karena tidak terdapat lekukan pada pagian sisinya. Pada busana adat daha dan truna Desa Bungaya penggunaan busana dan bentuk siluet sangat sederhana. 


\section{Pembahasan}

Busana adat daha dan truna Desa Bungaya merupakan busana tradisional yang tidak hanya digunakan untuk menyampaikan pesan-pesan mengenai nilai-nilai budaya yang pemahamannya dapat dilakukan melalui berbagai simbol yang tercermin dalam ragam hias pakaian adat tersebut (Agung, 2004: 7). Namun busana ini juga memiliki nilainilai estetis yang dapat dilihat secara nyata. Busana adat daha dan truna terbagi atas tiga bagian: (1) kepala, (2) badan dan (3) kaki. Untuk busana daha bagian kepala terdiri dari gelungan plendo, bunga onggar, bunga semanggi, pusung gaton yang dihias bunga serombyong (dibuat dari kertas putih), bunga sandat. Hiasan pada badan gelang perak pada dua pergelangan tangan, saput karah, senteng dan selendang yang dikenakan di bahu disebut sampet. Pada bagian bawah menggunakan kain tenunan Bali (bebas). Busana truna lebih sederhana jika dibandingkan dengan daha. Pada truna bagian kepala tidak menggunakan destar, pada bagian badan menggunakan kain untuk melelancingan, saput karah, umpal dan keris.

Bentuk busana adat daha dan truna Desa Bungaya Karangasem dapat ditinjau dari makna yang terkandung didalamnya. Semua makna budaya diciptakan dengan menggunakan simbol-simbol. Hal ini sesuai dengan teori Barthes untuk melihat makna konotatif dan makna denotatif. Terkadang semua orang seringkali menggunakan makna tetapi sering kali pula kita tidak memikirkan makna itu. Makna dalam satu bentuk atau bentuk lainnya, menyampaikan pengalaman sebagian besar umat manusia di semua masyarakat. Kesemuanya itu merupakan lingkup konotasi, beda halnya dengan pemakaian bahasa yang bersifat denotatif. Menurut Frank (1996:17), makna konotatif meliputi aspek makna yang berkaitan dengan perasaan dan emosi serta nilai-nilai kebudayaan dan ideologi. Menurut Piliang (1998:17), makna konotatif meliputi aspek makna yang berkaitan dengan perasaan dan emosi serta nilai-nilai kebudayaan dan ideologi. Untuk memahami makna konotatif, maka unsur-unsur yang lain harus dipahami pula. Sedangkan menurut Waridah (2008: 294) menyatakan bahwa makna denotative adalah makna suatu kata sesuai dengan konsep asalnya, apa adanya, tanpa mengalami perubahan makna atau penambahan makna. Menurut Piliang (1998:14) makna denotatif adalah hubungan eksplisit antara tanda dengan referensi atau realitas dalam pertandaan tahap denotatif. Hal ini juga dapat diartikan dengan apa yang dilihat itu yang disampaikan dan hanya berupa informasi data yang disampaikan.

a). Makna Denotatif yang ada dalam bentuk busana adat daha dan truna Desa Bungaya Karangasem.

Busana adat daha dan truna Desa Bungaya Karangasem memiliki bentukbentuk yang menyusun busana tersebut. Adapun makna denotatif yang pada busana adat daha dan truna Desa Bungaya Karangasem antara lain dalam bentuk geometris terdapat bentuk lingkaran, persegi dan persegi panjang. Pada bentuk non geometris juga terdapat bentuk dari gelungan dan keris. Selain itu juga terdapat bentuk siluet yang ada pada busana adat daha dan truna Desa Bun gaya Karangasem yang terdiri dari siluet $\mathrm{H}$ dan $\mathrm{I}$.

b). Makna Konotatif yang ada dalam bentuk busana adat daha dan truna Desa Bungaya Karangasem.

Seperti halnya yang sudah dijelaskan diatas, terdapat beberapa bentuk yang terdiri dari bentuk geometris, non geometris dan bentuk siluet yang ada pada busana adat daha dan truna Desa Bungaya. Adapun makna konotatif yang ada pada bentuk geometris terdapat bentuk lingkaran dimana dalam desain lingkaran adalah bentukyang tidak memiliki akhiran. Dimana lingkaran mewakilkan kekekalan, dan memberikan penekanan. Dalam suatu budaya lingkaran mewakilkan kekekalan dalam setiap budaya yang biasanya berbentuk matahari, bulan, alam semesta dan objek angkasa lainnya. Lingkaran juga 
disebutkan sebagai pembatas apa yang ada di dalam dan menjaga hal-hal lain tetap berada diluar. Selain itu lingkaran juga disebutkan sebagai komunitas, integritas dan kesempurnaan. Dalam busana adat daha dan truna Desa Bungaya penggunaan bentuk lingkaran memberi makna yang sesuai dengan yang dijelaskan diatas, bahwa lingkaran dapat dilambangkan sebagai bentuk dari alam semesta dimana lingkaran itu tidak memiliki awalan dan akhiran sama halnya dengan alam semesta, karena masyarakat di Desa Bungaya masih sangat memegang teguh kepercayaan untuk menjaga keseimbangan alam semesta beserta isinya dengan melakukan berbagai persembahan yadnya.

Selanjutnya terdapat juga bentuk persegi panjang, persegi panjang menunjukan kejujuran dan stabilitas. Selain itu persegi juga memberi makna sebagai pemberi kesesuaian, kedamaian, solidaritas, keamanan dan kesetaraan. Hal ini jika dikaitkan dengan bentuk pada busana adat tersebut memiliki keterkaitan yang dapat dibuktikan dari kehidupan masyarakat di Desa Bungaya mempersembahkan yadnya untuk memohon kedamaian dan kesejahteraan kepada Tuhan. Selain itu sikap gotong royong masih sangat dipegang erat sebagai salah satu hal yang sangat penting dalam kehidupan bermasyarakat di Desa Bungaya yang dapat dilihat dalam prosesi ngayah dalam setiap upacara-upacara di Desa Bungaya.

Pada bentuk non geometris juga terdapat bentuk flora. Bentuk flora ini adalah bentuk dari tumbuh-tumbuhan. Bentuk ini sudah terlihat jelas sebagai representasi dari isi alam semesta yaitu tumbuhan. Dalam kehidupan masyarakat Desa Bungaya, tumbunhan atau bunga erat kaitannya dengan seorang gadis. Dimana gadis di Desa Bungaya memegang peran penting dalam kehidupan social budaya di Desa Bungaya. Salah satu contohnya yaitu tradisi madaha dan matruna dimana dalam tradisi ini para remaja pria dan wanita disucikan untuk berhak masuk dalam organiasi adat daha dan truna. Dalam busana adat yang menggunakan bentuk floral terdapat pada gelungan yang digunakan oleh daha yang melambangkan sifat feminim dan kelembutan dari seorang wanita selain itu juga melambangkan keagungan dari seorang wanita. Sedangkan pada truna terdapat bentuk berupa keris. Keris merupakan senjata tradisional yang memiliki sisi tajam di kedua sisinya atau disebut bermata dua. Keris merupakan senjata tradisional yang sangat penting dakam kehidupan manusia pada jaman dulu hingga saat ini. Dalam kepercayaan Hindu keris sebagai senjata untuk melindungi diri atau keris juga sebagai benda magis untuk melindungi diri dari gangguan hal-hal negatif. Jadi dalam busana adat daha dan truna Desa Bungaya keris sebagai penjaga diri untuk kaun truna. Selain untuk penjaga diri, keris juga sebagai lambing dari kejantanan atau kegagahan seorang laki-laki khususnya truna Desa Bungaya.

Selain bentuk geometris dan non geometris dalam dunia mode atau busana bentuk menghasilkan siluet pada busana. Siluet $\mathrm{H}$ dan siluet I merupakan siluet yang membentuk busana adat daha dan truna Desa Bungaya. Siluet ini dalam dunia mode merupakan siluet yang paling simple dan sederhana. Kedua siluet ini terlihat lurus dan terdapat garis horizontal dan vertical.. Hal ini menunjukan makna bahwa masyarakat Desa Bungaya merupakan masyarakat yang sangat sederhana dan memiliki kekuatan/ stabilitas dalam mempertahankan adat dan istiadat yang sudah diwariskan namun dalam kekuatan itu juga terdapat ketenangan yang selalu disyukuri oleh masyarakat setempat dengan melakukan berbagai ritual usabal aci sebagai rasa syukur atas ketenangan, kesejahteraan dan kedamaian di Desa Bungaya. 


\section{Kesimpulan}

Busana Adat daha dan truna Desa Bungaya Karangasem yang sarat akan unsur-unsur seni, tradisi dan agama merupakan warisan leluhur yang patut dilestarikan. Dari berbagai unsurunsur yang terkandung didalamnya salah satu unsur yang menarik adalah bentuk pada busana tersebut. Dalam busana adat daha dan truna Desa Bungaya Karangasem terdapat bentuk geometris, non geometris dan bentuk siluet. Jika dilihat secara visual dapat disampaikan dengan makna denotatif, dan untuk mengetahui lebih dalam dilihat dari sudut pandang makna kontatif yang mengandung makna lain di dalamnya. Kajian bentuk dan makna pada busana adat daha dan truna Desa Bungaya Karangasem memiliki keunikan-keunikan yang seperti sudah dijelaskan di atas, dimana pada busana tersebut terdapat berbagai bentuk sederhana namun dibalik kesederhanaan itu terdapat nilai-nilai seni dan agama yang tidak dapat dipisahkan dari busana adat tersebut.

\section{Ucapan Terimakasih}

Puji syukur penulis panjatkan kepada Tuhan Yang Maha Ea, karena arikel ini dapat terselesaikan dengan tepat waktu. Penulis juga mengucapkan terimakasih sedalam-dalamnya kepada beberapa pihak yang telah membanru dalam melakukan penelitian, diantaranya:

1. De Salah Sukata selaku mantan kelian desa adat Desa Bungaya.

2. I Gede Yatha Wisnawa selaku penyarikan truna di Desa Bungaya Karangasem

3. Ni Made Sumerta selaku mekel daha nyomanan

4. Bapak I Gede Krisna Adiwidana selaku Sabha Kerta Desa Adat Bungaya

\section{Kepustakaan}

Agung, A. A. Ayu Ketut. (2004). Busana Adat Bali. Denpasar: Pustaka Bali Post

Bagus, Lorens. (2000). Kamus Filsafat. Jakarta: Gramedia Pustaka Utama.

Budiwanti, Erni. (2000). Islam Sasak: Wetu Telu Versus Waktu Lima. Yog akarta: PT. LKiS Pelangi Aksara.

Condronegoro, Mari S. (1995). Busana Adat Keraton Yogyakarta. Yogyakarta: Yayasan Pustaka Nusatama.

Feldman, E. B. (1997). Art as Image and Idea. New Jersey: Prentice Hall.

Gie, The Liang. (1996). Filsafat Seni Sebuah Pengantar. Yogyakarta: Karya Kencana.

Jekfins, Frank. (1996). Periklanan. Penerjemah Haris Munandar. Jakarta: Penerbit Erlangga, buku asli diterbitkan tahun 1985 .

Waridah, Ernawati. (2008). Ejaan Yang Disempurnakan dan Seputar Kebahasa Indonesia. Jakarta: Kawan.

Yasraf Amir Piliang, (2004). Semiotika Komunikasi, (Terj. Alex Sobur), Remaja Rosada Karya Bandung . 